\title{
The 'drifting Generation' without a Helmsman. Main obstacles in shaping the Relations between the Political Parties and the Youth in Poland
}

\author{
Radosław Marzęcki, Ph. D. ${ }^{1}$
}

\begin{abstract}
In the article the author presents data to identify the most important obstacles hindering efficient communication between political parties and Polish youth. The main assumptions accepted by the author are related to the belief that the Central and Eastern European countries are still trying to figure out ways of dealing with the key challenges related to transformation - the (re)creation of the civil society and a new, democratic culture of political discourse. Understanding that all social change is evolutionary and is a part of some social movement, the author assumes that the post-communist societies now face a chance to meaningfully accelerate this process. The chance is related to the young generation of citizens-often of the same age as the democracies themselves.
\end{abstract}

Keywords: youth; young voters; Poland; political party; party system; political communication; democracy; political culture; transformation

\section{Introduction}

It seems productive to view modern democracy from a normative standpoint and try to understand the institutions involved in a functional way. Each of these (parliaments, parties, mass media, universities, schools, NGOs etc.) has an important role to play in relation to its citizens. The importance of this role is even greater in countries with budding democracies, which have successfully transformed politically and economically, yet are still tackling the problems related to social changes (in terms of mentality, most popular attitudes toward the state and law or social capital). The quality of today's democracy depends to a large extent on the type of inputs that are coming from both the political elites and the citizens themselves (Easton, 1965, p. 32). The legitimisation of democracy depends on objective factors (efficacy and effectiveness of institutions (Linz, 1978, p. 16-24) but subjective factors also play a role (the sense of influence on the side of citizens (see: Linz and Stepan, 1996, p.17). It is those factors together

${ }^{1}$ Institute of Political Science, Pedagogical University of Cracow (POLAND) 
that shape common beliefs regarding the value of a political system. Therefore - from the point of view of stability of democracy - it is extremely important to strive for "a situation in which all the major political parties include supporters from many segments of the population" (Lipset, 1960, p. 31). Support on its own, however, is not enough. The type of relation that connects parties with the citizens is the most important here. In practice however, many party leaders often show neither a full understanding nor acceptance of the social role that ought to be played by political elites. This naturally leads to doubts and questions asked by the citizens: whom does democracy really serve ${ }^{2}$ ?

The political parties and their leaders form today a part of the so-called symbolic elite: groups and individuals controlling the social communication channels and engaged in shaping the vox populi (Czyżewski, Kowalski and Piotrowski, 1997, p. 17). Thus by changing the structure of the political discourse, these try to establish a separate "truth regime" and as a consequence gain control over the collective consciousness (Foucault, 1975, p. 30; 1977, p. 113-114, 2005). Their social status and resulting access to mass media means that the actions and opinions of politicians play an important role in the process of shaping the public's opinion (knowledge and ideology) with regard to a given area (van Dijk, 1993, p. 46-47, 2012, p. 17). In this sense, they are providing the key arguments for the legitimisation of democracy. The actions of politicians (especially the opinions they make public) have "a causal power, changing the system of interrelations between individuals and groups, influencing the shape of things", whereas "political declarations and manifestos provide interpretations of reality, valuation criteria, include to the circle of "our", providing energy required in performing specific actions, creating social facts" (Bartmiński, 2010, p. 16). Such power should also be connected with responsibility: "it seems obvious that politicians are responsible for shaping a specific view of the political class and many more phenomena present in collective consciousness and as a result the politicians are also responsible for the effects such components of consciousness would have for specific social activities" (Łabędź, 2003, p. 318).

2 "Competition", which for Joseph Schumpeter forms a part of the definition of democracy (Schumpeter, 1976, p. 269), is a good example here. In theory, it serves the citizens, who can choose from many competing political offers. This should result is a better quality "product", which is "bought" by the voter on the political market. In practice however, the competition can change political discourse into a destructive contest (antagonism), which provides the citizen with information not about the qualities of a given party but about the extent to which other parties are worse (Mouffe, 2005, p. 18). 


\section{Methodology and research problems}

This article is an attempt at identifying the most important obstacles hindering efficient communication between political parties and Polish youth. The problem itself, however, has much more general resonance and is not limited to the local situation in Poland. The main assumptions accepted by the author are related to the belief that the Central and Eastern European countries that began the democratisation processes in the 80 s and early 1990 s of the last century are still trying to figure out ways of dealing with the key challenges related to transformation - the (re)creation of the civil society and a new, democratic culture of political discourse. To a large extent, such problems are a result of many years of adaptation to a non-democratic system, which often meant acting in a noncivil way (for example corruption). In the words of Joseph L. Klesner: "in the former Soviet bloc, a long history of repression and surveillance discouraged people from broadly associating with others, which has led to political habits of apathy among citizens of those countries" $(2007$, p. 2). Democracy has enabled new mechanisms which were not "perfect" from the outset, were misunderstood by many and require a long-term adaptation (see: Agh, 2001).

Understanding that all social change (in terms of the culture of a given society) is evolutionary and is a part of some social movement, the author assumes that the post-communist societies now face a chance to meaningfully accelerate this process. The chance is related to the young generation of citizens - often of the same age as the democracies themselves. The attitudes and value systems represented in society are a result of interaction between two factors: (1) intentional or non-intentional influence of the older generations and (2) observations and adaptations to the current situation (political, economic and social) ${ }^{3}$. In this sense, each new society is constantly "becoming" (Sztompka, 1991, 1993). A new generation, which was not subjected to the influence of the non-democratic state, can - albeit this is only a possibility - become an initiator of changes (Inglehart, 1977; Inglehart and Welzel, 2005, p. 98). The "significant others" - parents, teachers, politicians, media - still have a marked influence on the views of young people. And this influence - especially in terms of promoting values which are important from the point of view of the "civic culture" such as trust, respect, solidarity, rules of the cultured debate, understanding, and respect for law - is not always positive. Therefore the author raises a number of research questions, including: Can typical traits of electoral behaviours of young

3 The citizens are constantly learning what is worth doing and what pays off by being symbolically rewarded or punished for their choices (Rosenstone and Hansen, 1993, p. 10). 
people be identified? What is the impact of these behaviours on the quality of our democracy? What role in shaping the democratic political culture is played by political parties? What are their primary mistakes? What factors and in which areas discourage young people from political involvement?

If the political parties want to be truly responsible for the quality of democracy, they cannot - in the long run - marginalise the youngest citizens. Such organisations, by definition, should mediate between society (individuals and groups) and politics. On the one hand, these organisations need social support, which translates to the energy with which they act; while on the other hand - in order to function properly - they have to efficiently diagnose and solve the problems of various social groups. The case of Poland shows - and that is the main research hypothesis - however that the parties seldom attempt to maintain long-lasting relations with the younger generation of voters do not pay attention to the problems the youth might have and do not treat these as important enough to be a part of public debate, and finally they instrumentally use their quantitative potential during elections in terms of the voting power represented by the young. In order to describe the most important obstacles, the author will quote data from their own research project that aimed at completely describing the social and political landscape of students in Poland, with an emphasis on the description of specific attitudes and behaviours undertaken by Polish youth during the 2011 presidential election. Given the necessity of taking into account both economic and organisational factors, the multi-stage sampling method was deemed the most appropriate one. Universites were determined as the first stage sampling units, followed by faculties in the second stage, institutes/departments in the third, main subjects in the fourth, and the academic years in the fifth. All the students from the randomly selected groups constituted the research group. In total, 994 students from 16 public academic institutions in Poland took part in a survey in mid-2012. It should be pointed out that the research group sampling method as described above does not permit to formulate direct generalised conclusions on the national level, but it can be assumed that the issues discussed in this article are quite universal, therefore better understanding of the "political parties-young citizens" relationship in general can be gained. Two important characteristics of the research group should also be noted, namely the sample size and the respondent age. $80 \%$ of the surveyed students were recruited from the age range 18-24, with an almost equal percentage of them (79\%) born in 1989 or later. The average age was 22 . The research group comprised $58 \%$ female and $42 \%$ male respondents, which corresponds to the gender structure recorded among Polish students ${ }^{4}$. The author also quotes the data related to a number of

4 During the analysis, the results were weighed in order for this disproportion to be 
international research projects (such as Eurobarometer, European Social Survey) and nationwide surveys conducted by respectable survey agencies in Poland. This is aimed at creating a proper context for the quoted arguments, allowing one to stronger emphasise a given problem or shed new light on the described matters. For that reason, the author also summarises the findings of the scientific discourse on the role and place of young citizens in the political processes.

\section{Programming the transformation}

Accepting a widely held view that system transformation can be defined as "a conglomerate of processes changing politics, economy and society" (Marzęcki, 2013a, p. 26), means that the evaluation of such changes has to take into account the multidimensionality of this phenomenon (Marody, 1996; Wnuk-Lipiński, 2005 , p. 49-50) ${ }^{5}$. In the long run, not only can the methods and implementation and control of the changes be evaluated but also the aims can be achieved. This is the approach represented by Claus Offe (2004), who suggests that two phases should be distinguished in the course of system transformations in postcommunist countries. The first is the rule introduction (design), the second being the effects of rules implementation. In terms of the first two dimensions (political and economic) the aims have been practically achieved. Democratisation, combined with the creation of the conditions favourable for the socio-political pluralism and change into market-oriented economy can be considered fait accompli. Notwithstanding them being important and undeniable achievements, it does not mean that these should not be criticised, especially with regard to those aspects that are not functioning properly. Given the necessity of constant effort aimed at improving the quality of democracy (Schmitter, 1994), such public debates - which do not negate the obvious achievements - are truly needed. The social effects of the transformation - our mentality, political culture, predominant attitudes in the public sphere - are however considered to be the most doubtful. Main points of criticism are related to the level of political (electoral, for the most part) participation, lack of interest in politics and public affairs or non-civic habits (e.g. low level of personal or institutional trust, no respect for law, amoral familiarism) (Sztompka, 2007, p. 265-301). Some of these are a result of adaptive strategies used during the non-democratic stage before 1989; it is important to notice however, that democracy also results in processes that can discourage individuals from active participation. The belief

corrected.

5 Dominika Kasprowicz uses the symbolic term: „turbulent era of transformation” (Kasprowicz, 2015: 158). 
that voting has little or no effect is a good example: individuals holding such a belief are often discouraged from acting. This paradoxical situation is described in a broader context by Marek Simlat, who points out a number of obstacles to public activity that are inherent to democracy itself, including: (1) a complex character of today's politics, requiring a citizen to have a better knowledge, the acquisition of which has high psychological $\operatorname{costs}^{6}$; (2) a diverse character of societies, generating various conflicts of interest, resulting in a cognitive and affective obstacle for civic competence; (3) the leading role of knowledge that brings power. As Simlat puts it, "citizens are being replaced with experts"; (4) an improper use of IT technologies, which "serve rather to increase control over citizens than to support interaction"; (5) the lack of trust in the representatives to support ordinary citizens in acquiring relevant competences and skills of social and political character (Simlat, 2008, p. 25-26).

In the social dimension, the aim of the transformation was the (re)creation of the civic society. A positive consolidation of a system has to always assume the embedding of democratic values on two levels: political elites and the public, and hence requires a recreation of the democratic political culture (Pridham, 1995, p. 166-203). In case of many Central and Eastern European Countries, this challenge has proved to be especially difficult as a result of the lack of democratic and civic traditions, which could serve as a valuable point of reference in creating positive behaviour patterns (Antoszewski 2000). It seems obvious that the change in terms of political culture can only happen over a longer stretch of time by stimulating long-term social practises, properly designing civic education or enabling political socialisation of the citizens (especially the young generation, which is not accustomed to the non-democratic practices). The mechanism of normative change, described by Ronald Inglehart, emphasises the youngest citizens (Inglehart, 1977). As Radosław Marzęcki writes in his commentary to Inglehart's conclusions, "each new generation, raised in conditions different than those before it, will contribute to the social life and public space a partially new set of norms and ways of interpreting reality, significantly influencing the changes in attitudes, values and behaviour patterns" (2013b, p. 63). Focusing educational efforts on the young generation is the most functional approach, as it takes into account the natural dynamics of social change. It is important that the institutions responsible for shaping a young citizen (school, university), and also the symbolic elites (politicians, media), understand the logic of this dynamics, as it is the "key" to the aim of the social transformation, which is still to be fully achieved.

6 In the long run, contemporary societies seem to be characterised by diminishing motivation to bear the costs of participating in elections (Marzęcki, 2013, p. 29-46). 


\section{Qualitative potential}

Despite the fact that the Polish society at large is getting older, the young are still a large social group, having an important qualitative capital. According to the data of The Central Statistical Office of Poland (GUS) (as of June 2014) there are 3446376 citizens in the age range 18-24. If, however, one accepts (an arbitrary) upper limit of 25 years of age, an additional 557519 citizens have to be taken into account (Table 1).

Table 1: The number of Polish citizens falling into one of the age ranges

\begin{tabular}{|l|c|}
\hline Age (range) & Number of citizens \\
\hline 18 & 430,106 \\
\hline 19 & 449,834 \\
\hline 20 & 473,228 \\
\hline 21 & 492,119 \\
\hline 22 & 516,574 \\
\hline 23 & 537,871 \\
\hline 24 & 546,644 \\
\hline 25 & 557,519 \\
\hline $\mathbf{1 8 - 2 4}$ & $\mathbf{3 , 4 4 6 , 3 7 6}$ \\
\hline $\mathbf{1 8 - 2 5}$ & $\mathbf{4 , 0 0 3 , 8 9 5}$ \\
\hline $\begin{array}{l}\text { Number of people eligible to vote in 2014 (European } \\
\text { Parliament Elections) }\end{array}$ & $30,636,537$ \\
\hline The population of Poles & $38,483,957$ \\
\hline
\end{tabular}

Source: Ludność. Stan i struktura w przekroju terytorialnym (Population. State and structure according to territory), GUS, Warszawa 2014.

In this sense "these play (...) an immensely important role in the process of legitimisation of a political system, hence in shaping and solidifying the social foundations of democracy" (Marzęcki, 2013b, p. 19-20). Such quantitative potential also has a more pragmatic dimension for it can significantly influence the final elections outcome ${ }^{7}$. For example, the two biggest Polish political parties (PO, PiS) each received about 2200000 votes in the 2014 EU parliamentary elections. (Table 2). In total, more than 7 million votes were cast on all the electoral committees. Hence, the number of representatives of the 18-25 age

7 E.g. in 2011 parliamentary elections, there were 30762931 eligible voters. 
range gives them the power, which - at least theoretically - can have a significant impact on the shape of the political scene.

Table 2: Number of votes cast on the political parties in the 2014 EU parliamentary elections

\begin{tabular}{|l|c|}
\hline Party & Number of votes \\
\hline Law and Justice (PiS) & $2,246,870$ \\
\hline Civic Platform (PO) & $2,271,215$ \\
\hline Democratic Left Alliance (SLD) & 667,319 \\
\hline Congress of the New Right (KNP) & 505,586 \\
\hline Polish People's Party (PSL) & 480,846 \\
\hline United Poland (SP) & 281,079 \\
\hline Europe Plus - Your Movement (EP TR) & 252,779 \\
\hline Poland Together (PR) & 223,733 \\
\hline National Movement (RN) & 98,626 \\
\hline All parties & $\mathbf{7 , 0 6 9 , 4 8 5}$ \\
\hline
\end{tabular}

Source: National Electoral Commission, http://www.pkw.gov.pl.

Traditionally, a low turnout in EU elections in a way "exaggerates" the true significance of a given group. The 2011 national parliamentary elections results gives in this sense a more realistic picture. The victorious Platforma Obywatelska (PO, Civic Platform) secured 5,629,773 votes, whereas Prawo i Sprawiedliwość (PiS, Law and Justice) received 4,295,016. Ruch Palikota (RP, Palikot Movement), which was often associated with the young voters, could count on $1,439,490$ votes, with the total number of votes being more than 14 million of Poles.

\section{How do the young vote?}

As it has been emphasised before, the youth's ability to fundamentally influence the structure of the representative institutions is of theoretical importance. This assumption is an important part of the thesis that there is not only qualitative but also quantitative ${ }^{9}$ potential in the young Poles. Their activity shows some 8 The number of young people (for example 18-25 years of age) eligible to vote in the elections.

9 Specific attitudes, norms, hierarchies of values, needs and difficulties experienced by 
characteristic features that force one to view the young voters in more realistic terms. These include:

- firstly: the voting preferences of young people are predictable: the structure of views is analogous to this of the society at large.

Table 3: Number of votes cast on the political parties in the 2011 national parliamentary elec-tions

\begin{tabular}{|l|c|}
\hline Party & Number of votes \\
\hline PO & $5,629,773$ \\
\hline PiS & $4,295,016$ \\
\hline RP & $1,439,490$ \\
\hline PSL & $1,201,628$ \\
\hline SLD & $1,184,303$ \\
\hline All parties & $14,369,503$ \\
\hline
\end{tabular}

Source: National Electoral Commission, http://www.pkw.gov.pl.

- secondly: young people are not a stable electorate: they prove disloyal to parties and change their preferences in a short amount of time (Table 4). On the basis of exit polls realised on the election day, one can infer that the majority of the young voters (18-25 age range) in 2011 elections supported PO, with PiS and $\mathrm{RP}$ coming second and third in terms of their preferences. This last party was the only one that in this age range secured more votes than in the population at large (10.02\%). During the 2014 EU parliamentary elections, it was Kongres Nowej Prawicy (KNP, Congress of the New Right) that secured the highest number of votes from the young. Whereas in local elections, held six months later, it was Prawo i Sprawiedliwośćc ${ }^{10}$.

the youth which affect their voting behaviours.

10 It is worth noting that both 2014 surveys, despite being realised by one surveying agency IPSOS, refer to different age ranges (18-25 and 18-29). Hence, in order to compare the two, one should perhaps focus on the "High school and university students" category, which was used in both cases. The support in this group in terms of European Parliament elections were distributed in the following manner: KNP $-28.4 \%$, PiS $20.4 \%$, PO - 19.6\%, SLD - 5.4\%, PSL - 5.3\%. Whereas in local elections: PiS $-26.7 \%$, PO $-20.5 \%$, KNP $-15.9 \%$, PSL - 13.9\%, SLD - 6\%, RN - 4.8\%. 
Table 4: Percentage of votes cast on the parties by the young voters

\begin{tabular}{|l|l|l|l|}
\hline Party* & $\begin{array}{l}2011 \\
(18-25 \text { age range })\end{array}$ & $\begin{array}{l}2014(\mathrm{EP}) \\
(18-25 \text { age range })\end{array}$ & $\begin{array}{l}2014 \text { (local) } \\
(18-29 \text { age range })\end{array}$ \\
\hline PO & $\mathbf{3 2 . 7 \%}$ & $19.3 \%$ & $22.5 \%$ \\
\hline PiS & $23.8 \%$ & $21.5 \%$ & $\mathbf{2 7 . 8 \%}$ \\
\hline RP & $23.3 \%$ & $5.5 \%\left(\right.$ EP TR $\left.^{* *}\right)$ & - \\
\hline PSL & $6.6 \%$ & $5.7 \%$ & $14.9 \%$ \\
\hline SLD & $6.1 \%$ & $5.1 \%$ & $6.1 \%$ \\
\hline
\end{tabular}

Source: Exit polls by IPSOS and TNS OBOP.

* the table contains the results of the selected political parties only

** Europa Plus Twój Ruch (Europe Plus - Your Movement)

- thirdly: young voters are aware of the weaknesses of current political offer, which on the one hand motivates them to choose "the lesser evil", and on the other hand means that they are more inclined to place trust in "new political initiatives". When answering the following question: "What was the main reason for you to vote on the representative of this particular party?" the students often emphasised motives that can be described as choosing "the lesser evil" (e.g. no competition; there was no-one to vote for; no alternatives; no other interesting candidate; no reasonable candidate; other parties were even worse; there was no other choice; negative selection) or "a new party" (e.g. longing for change; to give a chance to a new party; time for a change; others have ruled and it has not worked out; I want something new; new political power; new face of politics; new quality).

- fourthly (which describes arguably the most important feature): the young voters are the least motivated out of all the citizens to vote in elections (Bromley and Curtice, 2002; Park, 1999; Russell et al, 2002; Dermody and Hanmer-Lloyd, 2008). There was, however, a very interesting tendency revealed in an analysis of the Polish society (Graph 1). It turns out that during 1997-2011 the average turnout level in the 18-25 age range was increasing, whereas it was on the decrease for all the other age categories $(26+)$ as shown on the graph. 
Graph 1: Electoral turnout among young citizens and other voters

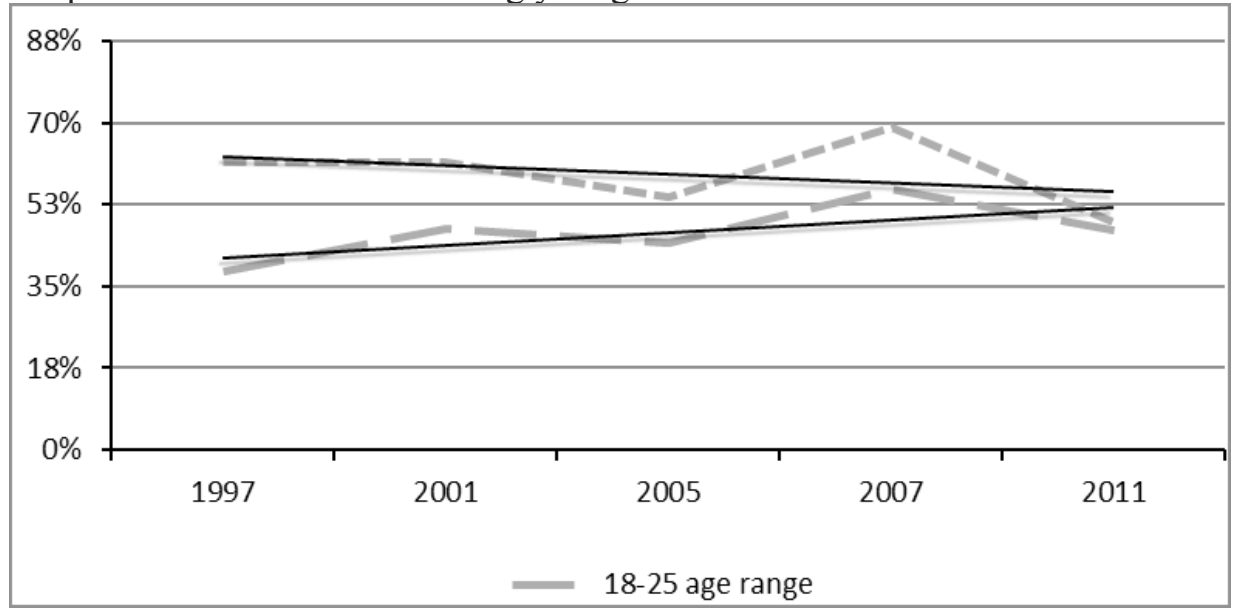

Source: Polskie Generalne Studium Wyborcze (Polish National Election Study) and OBOP.

\section{Main obstacles}

The abovementioned data and their analysis allows one to view the young generation of citizens as playing an important role in forming the social attitudes present in contemporary politics. The practise of political life shows however that the political parties are not fully tapping into this potential. This is often done by treating the young instrumentally and focusing on the quantitative character of their support with the particular electoral campaign in view. As a result, the young are still considered a "underdeveloped political niche" (Marzęcki, 2013d). When attempting to make this metaphor more concrete, one should try and identify the main obstacles that hinder the Polish political parties from establishing closer ties with the youth. Such obstacles have a varied source. On the one hand, these are created by political institutions and entities (parties, their leaders). On the other, they are a result of specific attitudes among the young (e.g. their relation to politics). Some are generated by difficult to control social processes (globalisation, mediatization of the social sphere or lifestyle changes). The obstacles are related to various aspects of the socio-political life, including: 


\section{1) Language and Communication}

In a media driven world, the mass media are more and more important in terms of informing about the important events (Hjarvard, 2008, p. 113). The phenomenon of mediatization concerns the society at large but also all its subsystems, including politics. It is the media coverage (which is to a large extent inspired by the politicians) that shapes the main interpretation framework of contemporary politics and serves as an important suggestion to the viewer - not so much what to think but about what (the topics) to think (McCombs, 2004; Strömbäck and Dimitrova, 2006; Strömbäck and Luengo, 2008). The power exercised by mass media becomes attractive to political parties, striving to utilise this tool in the political fight for the control over the discursive power. Andrzej Antoszewski writes that the aim of the participants of a political struggle is always to gain access to power, to change the division of power between various political forces, or to keep the power $(2004$, p. 15). The permanent character of today's election campaigns (Blumenthal, 1982; Helco, 2000, p. 17; Charnock, 2005, p. 18) means that the competition "takes place in different areas - any place where the representatives of various parties can interact with each other" (Marzęcki, 2013a, p. 17). Hence, the language of politics, shaping the political discourse serves to create one-sided interpretations, and not descriptions, of reality. In addition, we observe, what many researchers call the displacing of the model of democratic politics where the emphasis is on dialogue, deliberation and search for a common ground with the society; by a model based on administration (hence imposing regulations and entering into dialogue only when met with social resistance) (Król, 2012; Habermas, 2012). All this is extremely destructive for society, which has no opportunity to forge an autonomous opinion on many problems of public importance. The direct experiences of an individual trying to consciously analyse the socio-political life cease to be a source for opinions. Instead, mass media are becoming an indirect source of information in an ever increasing number of situations (Sztompka, 2007, p. 340-341). This phenomenon is already described by Charles Wright Mills in The Power Elite (1956), arguing that historically one can and should observe the transformations of societies towards the mass model. He claims that this type of transformation, since the first half of the nineteenth century, has been one of the main characteristic features of modern societies. This "mass" character of politics means - according to Mills that everyone is an object exposed to information and propaganda content.

The commercialised logic of media forces it to "colonise" contemporary politics, pushing politicians to calculate the pay-offs related to their various behaviours from the point of view of their main aim: the struggle to gain or 
remain in power (Strömbäck, 2008, p. 240; Wayne, Mackenzie and Cole, 2006, p. 344). The visibility in mainstream media is obviously a more efficient and cost-effective strategy than the meetings (in most cases the most interesting anyway) for voters. The media transmission is one-directional. The viewer, reader or listener plays a passive role of a receiver, which only serves to provide further support for the belief that he or she has no impact on politics. Such people easily find excuses for their lack of motivation in terms of participation: "The result of the election will be the same whether they participate or not" (Rosenstone and Hansen, 1993, p. 21). It is especially young people that often justify their withdrawal from the political sphere in the following way: I do not vote because my vote does not really matter; in the end, everything is decided by the politicians. At the same time, as confirmed by the Euro barometer survey, participation in political debates is considered by the youth the most efficient way of influencing politics (Flash Eurobarometer 202). Analysing the relations between political, media and social spheres, we conclude that all these are indeed interconnected or even dependent on each other. Setting the criteria for topic selection, mass media forces politicians to adapt. The resulting phenomena (e.g. stimulating political conflict, incendiary language, remembering old division lines, not taking new phenomena and social changes into account), makes politics all the less appealing in the eyes of young citizens. John C. Green and Daniel M. Shea point out that the "new style" in politics, focused on negative campaigns, media coverage of sensational information and big money often politically alienates young people (2007, p. 21; see: Hayes, Scheufele and Huge, 2006). All this is aptly summarised in a quotation from Pokolenie '89. Aksjologia i aktywność mlodych Polaków (Generation 1989. Axiology and Activity of Young Poles): "The problem with which the political elites - so far - have not been able to solve, is the communication with the youth: it has to take into account the dynamics of changes in attitudes and values, should be expressed in a language that is considered by them more natural and not stilted, finally - it should be able to shorten the distance between the young citizen and the politician, whom the former often views as unreliable and disgraced" (Guzik, Marzęcki and Stach, 2015, p. 48).

\section{2) The Image of Political Parties}

It is precisely the lack of reliability of the political class that creates another obstacle hindering the establishment of stronger relations between political parties and young people. What should be emphasised is the level of criticism expressed by the young, which is often further generalised. Table 5 contains the 
summary of value judgements made by students in relation to the impact that particular political parties have on Polish politics. The respondents were asked to express their opinions using a 5-leveled scale, where "1" meant negative opinions, and "5" meant positive. The mean value of " 3.00 " meant a balance between positive and negative, with no political party moving beyond this point toward the positive extreme. Platforma Obywatelska (with 2.96), was the bestvalued party, whereas Prawo i Sprawiedliwość scored the lowest (2.34). The differences in average values are small and - as it seems - are less significant than the conclusion that all the parties are equally bad.

Table 5: The evaluation of an impact of particular parties on the political scene made by Polish students ( $\mathrm{N}=994)$

\begin{tabular}{|l|c|}
\hline $\begin{array}{l}\text { In your opinion what is the impact of particular parties (fac-tions) on Polish } \\
\text { politics. "1" means: "very negative", and "5" - "very positive" }\end{array}$ \\
\hline & Average from the 1-5 scale \\
\hline PO & 2.96 \\
\hline PSL & 2.87 \\
\hline SLD & 2.77 \\
\hline RP (TR*) & 2.75 \\
\hline PJN** & 2.56 \\
\hline SP & 2.45 \\
\hline NP & 2.39 \\
\hline PPP*** & 2.36 \\
\hline PiS & 2.34 \\
\hline
\end{tabular}

Source: author's own study.

* TR (Your Movement) ** PJN (Poland Comes First); *** PPP (Polish Labour Party)

The importance of this obstacle is even greater when one considers other data indicating a crisis in political leadership (Marzęcki, 2013c). Party leaders who are consistently viewed as dishonest, unreliable, driven by pursuit of power and money and mainly looking after their particular affairs are not deemed respectful enough to promote good standards of civic behaviour (Table 6). 
Table 6: Polish students on political class ( $\mathrm{N}=994)$

\begin{tabular}{|l|c|}
\hline \multicolumn{2}{|l|}{$\begin{array}{l}\text { How would you describe politicians in general? In your opinion, are they } \\
\text { predominantly }\end{array}$} \\
\hline Honest & $3 \%$ \\
\hline Dishonest & $69 \%$ \\
\hline Don't know & $28 \%$ \\
\hline Reliable & $4 \%$ \\
\hline Unreliable & $78 \%$ \\
\hline Don't know & $18 \%$ \\
\hline Care about Poland & $4 \%$ \\
\hline Care about themselves & $79 \%$ \\
\hline Don't know & $17 \%$ \\
\hline
\end{tabular}

Source: author's own study.

Locating this problem in a broader context, as set out in the title of this article, it is worthwhile asking two questions regarding the role the political elite plays in the life of the young generation. Firstly, who in the eyes of the young generation has enough authority to help reinforce the positive - civic - patterns of behaviour? Is there anyone the young would listen to? Secondly, what kind of patterns are in reality reinforced in the young generation? Meaning, in what sort of a way does politics eventually represent itself to the young?

\section{3) Political Programmes}

These kind of obstacles are an effect of no - or weak - relation between the political programmes (but also the public/political discourse by means of which it is communicated) and the real problems of the young generation. The objective quality of what is being offered is also problematic, that is the level of detail of the diagnoses of the problems of the youth and the ways in which to tackle these are considered insufficient. What is often emphasised about political programmes is their general character (Marmola, 2012). If during electoral campaigns the candidates "ought to" refer to the problems of the young generation, this in most cases translates into no specific actions. Particular solutions to such problems are rarely treated seriously enough as to become a cause of serious disagreement between various political parties. Yet, it is very easy to identify the areas that young people find the most problematic. The students who participated in the survey were asked an open question (without hinting at any particular answer) 
about what in their opinion is the biggest problem of the young generation of Poles. An overwhelming majority (more than 90\%) of answers can be categorised as related to "unemployment and economic situation". This category included the following problems: unemployment, low pay for inexperienced workers, no perspectives, rapacious capitalism, unemployment despite higher education, general situation on the job market, "junk contracts", difficult initiation into adult life, no well-paid jobs, no decent job, no future perspectives, no jobs and no place to live, no work that would prove interesting and well-paid, no chance for development, expensive housing. The next category of answers given by respondents (amounting to less than $10 \%$ of the total) was related to the perceived problems with education: problematic structure of universities, no match between education and job market, education, problems with education, low quality of studies, level of Polish education, hopeless education system. The following problems were quoted with the smallest frequency (less than 5\%): high crime rate, influence of Church, lack of authorities, alcoholism, no tolerance, parochialism, no sensitivity, consumerism, addiction, drugs, the rate of future retirement pensions.

Such a hierarchy of problems is also confirmed by the distribution of the answers to the closed question about which of the suggested topics is according to the respondent the closest to young people (Table 7). It turns out that the economy-related issues (unemployment, job market, wages, taxes etc.) and social problems (health services, education, transportation, culture etc.) were among the most frequently chosen.

The survey results allow one to infer that, in this context, the most often expressed wish of the young Poles is that the political elites act against marginalisation of the young generation (Graph 2). This subjective feeling, which is one of the most important obstacles hindering youth from engaging more in politics, is predominantly related to the belief that the political parties do not wish to focus on the problems of the young and are passive in terms of addressing these. 
Table 7: Importance of particular topics for citizens $(\mathrm{N}=994)$

\begin{tabular}{|l|c|}
\hline $\begin{array}{l}\text { Which of the following issues do you believe are the most } \\
\text { important for young people? }\end{array}$ & Average \\
\hline $\begin{array}{l}\text { Please, arrange them on a scale of "1" (the most important) to } \\
\text { "5" (the lease important) }\end{array}$ & 1.73 \\
\hline $\begin{array}{l}\text { Economic issues (unemployment, employment, salary, taxes, } \\
\text { etc.) }\end{array}$ & 2.41 \\
\hline $\begin{array}{l}\text { Social issues (health care, education, transportation, culture, } \\
\text { etc.) }\end{array}$ & 2.47 \\
\hline $\begin{array}{l}\text { World views (state-church relationship, abortion, civil uni- } \\
\text { ons, legalisation of drugs, etc.) }\end{array}$ & 3.72 \\
\hline $\begin{array}{l}\text { Political issues (vision of state, financing of political parties, } \\
\text { foreign policy, etc.) }\end{array}$ & 4.39 \\
\hline $\begin{array}{l}\text { Historical issues (assessment of the past, historical policy, } \\
\text { etc.) }\end{array}$ & \\
\hline
\end{tabular}

Source: author's own study.

Graph 2: Polish students' ideas on how to increase the levels of electoral turnout $(\mathrm{N}=994)$

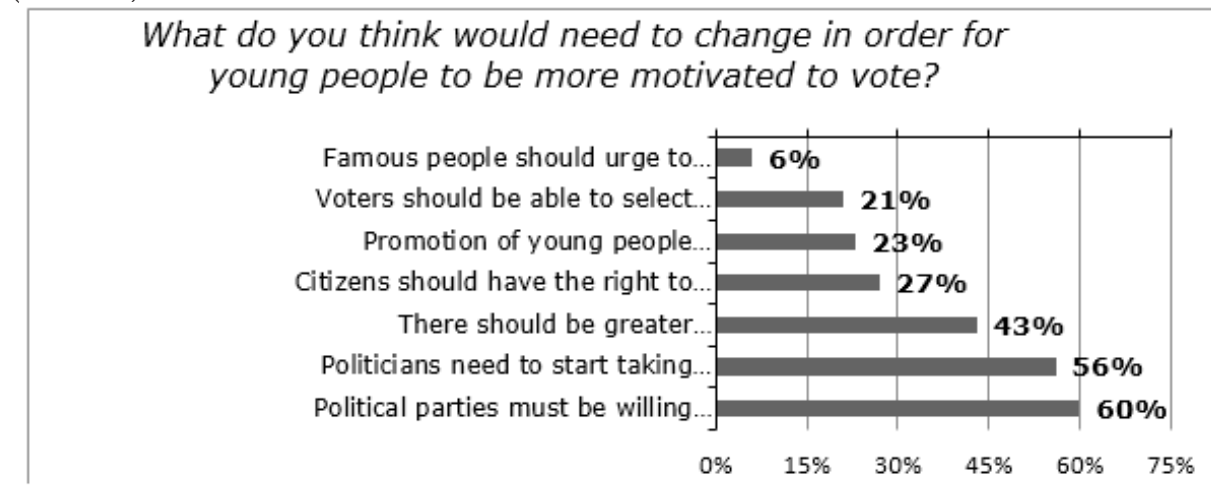

* Percentages do not sum up to 100 , as the respondents could tick more than one answer

Source: author's own study. 
Most of the respondents emphasise that their biggest problems, issues and opinions are neglected in the public discourse (Table 8).

Table 8: Polish students on the public discourse ( $\mathrm{N}=994)$

In your opinion, are the problems and issues of the young people sufficiently represented in the public discourse?

\begin{tabular}{|l|c|}
\hline Yes & $5 \%$ \\
\hline No & $81 \%$ \\
\hline Don't know & $14 \%$ \\
\hline
\end{tabular}

Source: author's own study.

\section{4) Relations Between Parties and the Public}

The main source of frustration in this context is the low level identification of the youth with the political parties. This phenomenon is a characteristic of Polish society at large but in the young generation it is especially evident. In a broader context this relates to - an objective - problem of low representativeness of political parties which are unable to come up with a political programme that would correspond with the expectations of the society. This problem can, however, be analysed from a subjective point of view and understand it as a belief of the citizens that the parties care only about their own well-being and not about the well-being of the society as such (or their electorate). The dysfunctional character of the relations between the parties and the young people results in:

(1) negative views of these organisations, e.g. the belief that political parties are not trying to solve the problems important from the point of view of the young people (Table 9):

(2) the belief that the political parties are unreliable. For example, $21 \%$ of young supporters of Ruch Palikota when surveyed were fully convinced that the party they had voted for will not realise "any" of the promises made during the campaign. In another case, $16 \%$ of them expressed belief that this party is unreliable (with only $2 \%$ believing Ruch Palikota is fully reliable).

(3) the lack of collaboration between the young people and the political parties. Available data suggests that the activity of young Poles in voluntary organisations, if at all, is most often limited to non-political contexts (sport clubs, cultural and religious organisations). 
Table 9: Polish students on representativeness of political parties ( $\mathrm{N}=994)$

\begin{tabular}{|l|c|}
\hline $\begin{array}{l}\text { To what extent do political parties represent young peo- } \\
\text { ple's interests? ("1" } 1 \text { - not to the least extent, "5" - to the } \\
\text { greatest extent) }\end{array}$ & Average \\
\hline RP & 3.33 \\
\hline PO & 2.65 \\
\hline SLD & 2.60 \\
\hline KNP & 2.46 \\
\hline PJN & 2.27 \\
\hline PiS & 2.20 \\
\hline SP & 2.10 \\
\hline PSL & 2.07 \\
\hline PPP & 1.99 \\
\hline
\end{tabular}

Source: author's own study.

(4) the belief that the political parties are unreliable. For example, $21 \%$ of young supporters of Ruch Palikota when surveyed were fully convinced that the party they had voted for will not realise "any" of the promises made during the campaign. In another case, $16 \%$ of them expressed belief that this party is unreliable (with only $2 \%$ believing Ruch Palikota is fully reliable).

(5) the lack of collaboration between the young people and the political parties. Available data suggests that the activity of young Poles in voluntary organisations, if at all, is most often limited to non-political contexts (sport clubs, cultural and religious organisations).

It is worth noticing that merely one fourth of Poles admits to any sort of relation with the political parties (Table 10). This includes people who describe their relation as "identifying" with a party and those that emphasise a weak character of this relation. On the other hand, up to $72 \%$ admit that they do not feel any affinity with a party or political faction. 
Table 10: The sense of relation of Poles with particular groups and social circles

\begin{tabular}{|c|c|c|c|c|}
\hline \multicolumn{5}{|c|}{$\begin{array}{l}\text { How strongly do you feel the affinity with the following groups and social } \\
\text { circles? }\end{array}$} \\
\hline & \multicolumn{2}{|c|}{$\begin{array}{l}\text { I feel affinity } \\
\text { (identification, strong affi- } \\
\text { nity, weak affinity) }\end{array}$} & \multicolumn{2}{|c|}{$\begin{array}{l}\text { I feel no affinity and no } \\
\text { identifi-cation }\end{array}$} \\
\hline & Total & $\begin{array}{l}18-24 \text { age } \\
\text { range }\end{array}$ & Total & $\begin{array}{l}18-24 \text { age } \\
\text { range }\end{array}$ \\
\hline Family & $99 \%$ & - & $0 \%$ & - \\
\hline $\begin{array}{l}\text { Relatives and clo- } \\
\text { sest friends }\end{array}$ & $98 \%$ & - & $1 \%$ & - \\
\hline Poland & $95 \%$ & $73 \%$ & $2 \%$ & $5 \%$ \\
\hline My nation & $95 \%$ & $96 \%$ & $2 \%$ & $4 \%$ \\
\hline The city I live in & $95 \%$ & $94 \%$ & $4 \%$ & $7 \%$ \\
\hline Region & $88 \%$ & $89 \%$ & $10 \%$ & $9 \%$ \\
\hline Europe & $80 \%$ & $89 \%$ & $15 \%$ & $9 \%$ \\
\hline $\begin{array}{l}\text { My professional } \\
\text { group }\end{array}$ & $72 \%$ & $71 \%$ & $21 \%$ & $23 \%$ \\
\hline My place of work & $64 \%$ & $54 \%$ & $25 \%$ & $27 \%$ \\
\hline $\begin{array}{l}\text { An organisation or } \\
\text { society }\end{array}$ & $27 \%$ & $37 \%$ & $66 \%$ & $61 \%$ \\
\hline $\begin{array}{l}\text { A party or political } \\
\text { faction }\end{array}$ & $25 \%$ & $24 \%$ & $72 \%$ & $75 \%$ \\
\hline
\end{tabular}

Source: own analysis on the basis of: Co taczy Polaków? (What connects Poles?), CBOS Report, BS/168/2013, http://www.cbos.pl.

INFORMATION: The table does not contain the data related to "Don't know" category.

Another important observation is that the described problems distinguish the Polish society from other European ones, including - interestingly - other post-communist countries (Table 11). The feeling of an affinity with political parties is much stronger in Bulgaria or Slovakia, as indicated by the European Social Survey data. In the survey (Round 6) realised in a similar period to our student survey, $27 \%$ of adult Poles described themselves as a sympathiser of some party, with only $8 \%$ stating that this relation is "very close". The subjective belief about the connection with political parties is much less prominent among 
young citizens (18-24 years of age), which is characteristic of many European countries. It is, however, very symptomatic of the young Poles, out of which only $12 \%$ declare any sort of connection with a political party.

Table 11: The affinity with political parties in chosen European countries

\begin{tabular}{|l|c|c|c|c|}
\hline \multirow{2}{*}{$\begin{array}{l}\text { Is there any political party with which you feel more connected than with the } \\
\text { other parties or you would consider yourself its sympathiser? }\end{array}$} \\
\hline & \multicolumn{2}{|c|}{ Yes } & \multicolumn{2}{c|}{ No } \\
\hline Total & $\begin{array}{c}18-24 \text { age } \\
\text { range }\end{array}$ & Total & $\begin{array}{c}18-24 \text { age } \\
\text { range }\end{array}$ \\
\hline Danmark & $71 \%$ & $65 \%$ & $29 \%$ & $35 \%$ \\
\hline Netherlands & $61 \%$ & $48 \%$ & $39 \%$ & $52 \%$ \\
\hline Switzerland & $57 \%$ & $40 \%$ & $43 \%$ & $60 \%$ \\
\hline Belgium & $52 \%$ & $41 \%$ & $48 \%$ & $59 \%$ \\
\hline Bulgaria & $52 \%$ & $35 \%$ & $48 \%$ & $65 \%$ \\
\hline Germany & $51 \%$ & $45 \%$ & $49 \%$ & $55 \%$ \\
\hline Great Britain & $47 \%$ & $24 \%$ & $53 \%$ & $76 \%$ \\
\hline Slovakia & $43 \%$ & $28 \%$ & $57 \%$ & $72 \%$ \\
\hline Spain & $42 \%$ & $33 \%$ & $58 \%$ & $67 \%$ \\
\hline Portugal & $36 \%$ & $27 \%$ & $64 \%$ & $73 \%$ \\
\hline Czech Republic & $33 \%$ & $14 \%$ & $67 \%$ & $86 \%$ \\
\hline POLAND & $27 \%$ & $12 \%$ & $73 \%$ & $88 \%$ \\
\hline
\end{tabular}

Source: own analysis on the basis of ESS Round 6 (2012) data.

It is often emphasised that the belief that one's actions are meaningful is one of the factors determining political (and electoral) participation. The stronger the belief, the more probable it is that this action will be undertaken. Most adult electorates of the parties admit that there is no single political party that fully deserves a vote in parliamentary elections (Table 12). It turns out however that even if the young voters do decide to take part in elections, their vote has a ritual character and is made without the accompanying belief in its rightfulness. Whereas $69 \%$ of the Poles hold such views, among the young citizens (18-24 age range) this percentage jumps to $78 \%{ }^{11}$.

11 Jakiej partii potrzebują Polacy (What party do the Poles need?), CBOS Report, BS/123/2013, http://www.cbos.pl. 
Table 12: The level of conviction in voting for particular political parties

\begin{tabular}{|c|c|c|c|}
\hline \multicolumn{4}{|c|}{$\begin{array}{l}\text { Is there a political party in Poland for which you could vote with full convic- } \\
\text { tion in parliamen-tary elections? }\end{array}$} \\
\hline Party electorates & Yes & No & Don't know \\
\hline $\mathrm{PO}$ & $38 \%$ & $58 \%$ & $4 \%$ \\
\hline PSL & $32 \%$ & $66 \%$ & $2 \%$ \\
\hline$\overline{\mathrm{PiS}}$ & $60 \%$ & $36 \%$ & $4 \%$ \\
\hline SLD & $40 \%$ & $60 \%$ & $0 \%$ \\
\hline Others & $37 \%$ & $58 \%$ & $5 \%$ \\
\hline Undecided & $10 \%$ & $80 \%$ & $10 \%$ \\
\hline Non-voting & $12 \%$ & $83 \%$ & $5 \%$ \\
\hline
\end{tabular}

Source: Jakiej partii potrzebuja Polacy? (What party do the Poles need?), CBOS Report, BS/123/2013, http://www.cbos.pl.

The group of factors presented above shows that the character of relation between political parties and society, especially the young generation, is not a tight one. The parties, which by definition should play the role of a mediator between the citizen and the political system, are viewed as entities that are actually not even interested in this kind of mediation. According to many young Poles, the parties do not represent their beliefs, views or what is important to them, hence if the citizens do engage in the political life (elections), it is often done without conviction.

\section{5) Social}

In this respect, all the limitations are related to the fact that political parties do not seem to be interested in important - long-range and broad in character - social trends, e.g., the lifestyle changes of the youth. In relation to several indicators, one can even venture to use the phrase "de-politicisation" to describe a new lifestyle, where politics is all but marginal (Marzęcki, 2015).

The scientific description of the political participation of the youth - as pointed out by Siyka Kovacheva - does pay attention to more long-lasting attitudes, using the phrases as e.g.: "abandoning of civic rights" (Adsett, 2003), the collapse of political capital, "de-politicisation" of youth (Vrcan, 2002), "weakness of society" (Tivadar, Polona, 2002), "marginalisation" (Svynarenko, 2001) or "anomy" (Adnanes, 2000). These are rarely considered to be an expression and effect of the lifestyle changes of the youth. As Radosław Marzęcki emphasises, 
"the new model of everyday behaviour in essence neglects politics and all that is political as unattractive. In the hierarchy of values, the politics and governing (in a broader sense) occupy distant places. Politics is neither a way to fill in youth's free time, which is more eagerly devoted to entertainment. It is hardly a way of spending the time free from work (e.g. as a conversation topic)" (Marzęcki, 2015).

The main symptoms of such de-politicisation are as follows:

(1) low position of politics in the hierarchy of everyday needs;

(2) not following political news presented in media;

(3) rarely engaging in conversations on politics (with family, friends);

(4) entertainment-oriented rather than socio-political activities in free time (e.g. voluntary work);

(5) the weakening of hierarchical authorities (e.g. the country, political parties) (Inglehart, 1999: 250:251; Dermody and Hanmer-Lloyd, 2008: $155)$.

As previously mentioned, we should emphasise that the mentioned phenomena are not unique to young people but rather describe universal features of many societies. Paul Howe points out that - for example not voting in the elections firstly, is not limited to the youngest citizens and secondly, that it is not a recent phenomenon (2006, p. 138). Political apathy or alienation are characteristic of a tendency, which - to a various extent - is a part of all societies. Many authors describe modern Western societies as de-politicised (Terrén, 2002, p. 167), emphasising the apathy of the young generation (Tyyskä, 2009, p. 151). Such explanation seems rational in the view of the fact that the normative changes happening in these societies in the 1970s (towards greater acceptance of postmaterial values) and related consequences (e.g. the collapse of hierarchy-based authorities) were reflected stronger in the attitudes of the youth. It is them, being raised in welfare states (having physical and social security), who strengthened the patterns of behaviour, where distancing oneself from formal - traditionally conceived - politics is important (Inglehart, 1999, p. 236). De-politicisation is a phrase that also seems fitting to describe the situation in post-communist countries. There too the change in terms of accepted norms and hierarchy of values that influences politics (e.g. by impacting the political discourse or even shaping political elites) is still under way. Hanna Palska describes this in the following manner: "the Western paragons, fads and subcultures, after the collapse of political barriers, have - almost overnight - influenced everyday life in Poland" (2009, p. 122). New possibilities, given by the modern integrated and globalised world are considered by the youth as very alluring, with politics 
becoming just one of the topics of interest. That the normative change is under way is undeniable. Unwillingness to understand its essence will contribute to self-fulfilment of the pessimistic widespread prophecy: the youth will not be motivated enough to share the responsibility for the country and will not pass the belief in the need of such behaviour to the next generations.

\section{6) Political}

The causes of certain obstacles reside on the side of the political parties. One should emphasise that the first experiences of political participation are the most important from the point of view of future attitudes in this respect (Kovacheva, 2005 , p. 22). For this very reason, certain symbolic situations are considered by the young voter (without the developed interest in politics) important milestones used for future value judgements in relation to political participation. These are later used in order to decide whether the given psychological costs of participation are worth bearing. Yet, the political practice shows that the negative patterns are being strengthened in terms of relations between the parties (politicians) and the young generation. It is important to emphasise the following points:

(1) inability or even unwillingness on the side of a party to establish long term relations with young voters;

(2) instrumental approach to the young people's potential (limited to preelection mobilisation);

(3) no continuity in terms of dealing with the problems raised after the electoral campaign ends; Ruch Palikota prior and after the 2011 parliamentary elections serves as a prime example here. The language, content and form of the electoral campaign (heavily oriented on the young voters) were abandoned in a couple of months after the elections with the leader - by inciting conflicts over the leadership of the left - sent a message to the young voters that the main points of the campaign will cease to be important parts of the public (media) discourse. Many of the previous supporters of Ruch Palikota felt disappointed with such an approach, as indicated by the results of the student survey conducted a couple of months after the elections (Table 13). It turns out that after such a short period, only over half $(52 \%)$ of young people that had voted for RP declared they would support it again. The youngest voters, hence those that often have not voted before, have plenty of reasons to be dissatisfied with their initial voting experience and that can influence their future attitudes as voting (or non-voting) citizens (Russell et al, 2002). 
Table 13: The decisions of students who voted on Ruch Palikota (in the middle of 2012) ( $\mathrm{N}=168)$

\begin{tabular}{|c|c|}
\hline \multicolumn{2}{|c|}{$\begin{array}{l}\text { If the parliamentary elections were organised on the coming Sunday, which } \\
\text { party would you vote for? } \\
\text { (results for the voters that supported RUCH PALIKOTA) }\end{array}$} \\
\hline The same as before & $52 \%$ \\
\hline Other & $14 \%$ \\
\hline I will not vote & $8 \%$ \\
\hline Don't know & $26 \%$ \\
\hline
\end{tabular}

Source: author's own study.

\section{7) Promotional}

It has been mentioned that the political parties are not very attractive (as reflected in the youth's disinterest in how the parties operate) and negative (the parties and politicians tend to shape non-civic behaviour patterns) in the eyes of the young generation. In this context, it is worth emphasising that the political parties are absent from the area where the shaping of valuable attitudes is efficient and targets large numbers of citizens. What is meant here is the PR and (social) advertising. The lack of consistent promotional strategy (aimed to encourage citizen participation) is evident on the side of political parties and NGOs alike (social advertising). The latter are often treated by politicians with mistrust. This should serve as a motivation for a broader discussion on the role political elites and mass media are to play in shaping the structure (in terms of the importance of topics covered) of public debate, mainly during electoral campaign season. To what extent should this be an opportunity for politicians to present - often emotion-laden - content, and to what extent should it serve to educate citizens and aid in their political socialisation?

\section{8) Structural (Human Resources)}

The young people are not only marginalised in terms of public discourse or political programmes but - as they so often emphasise - have a hard way in terms of being promoted within the political hierarchies. One of the results of "obstructed" promotion channels is, for example, non-representative characters of many public or political institutions (this is true of many countries; see: Mahidi, 2010, p. 59). For example in the Polish parliament, the youngest political 
representatives (below 30 years of age) are merely $2 \%$ of all the MPs (Table 14).

Table 14: Age structure of 7th Turn Sejm MPs (2011-2015)

\begin{tabular}{|l|l|l|l|l|l|l|}
\hline & $\begin{array}{l}\text { Below } \\
30\end{array}$ & $30-39$ & $40-49$ & $50-59$ & $60-69$ & $\begin{array}{l}\text { Above } \\
70\end{array}$ \\
\hline Number & 10 & 86 & 135 & 160 & 66 & 3 \\
\hline $\begin{array}{l}\text { Percen- } \\
\text { tage }\end{array}$ & $2 \%$ & $19 \%$ & $29 \%$ & $35 \%$ & $14 \%$ & $1 \%$ \\
\hline
\end{tabular}

Source: http://www.sejm.gov.pl.

The lack of selection and search mechanisms for potential social leaders is yet another problem that should be pointed out. The political parties require loyalty and subordination, whereas the youth, often insubordinate and full of creative ideas, do not fit the criteria of "obedient" membership.

\section{9) Perceptual}

The last of the discussed obstacles is related to the processes of shaping the citizen's opinions on publicly important topics. As it has been mentioned above, in the mediatized world, most information shaping our knowledge base about the environment comes from the mass media. It is mass media that defines the limits of perception of the political scene and provides interpretation for the events. The amount of media time devoted to each political party or candidate relates to the way in which the entire political scene is perceived, according to the principle stating that media are not so much trying to impose on the receiver what to think but rather about what to think. In Poland after 2005, it is both Platforma Obywatelska and Prawo i Sprawiedliwość that receive the biggest share of media coverage. Media often focus on those parliamentary factions (parliamentary clubs), the representatives of which are invited to current affairs programmes. The scarcity of pre-election debates or organising these according to the media logic (the primacy of viewer figures, emphasis on simplicity), which often contradicts the assumptions of democracy itself (where prioritising the equal share in media access is emphasised) is a cause of concern. Such practices are the most damaging to those voters that are characterised by low levels of the so-called political sophistication, hence lacking political knowledge or interest in political affairs (Luskin, 1987, p. 856-899, 2003, p. 238; Zaller, 1992, p. 333; de Vreese and Boomgaarden, 2006, p. 34; Haack, 2007, p. 24). Naturally, many young people do fall into this category. Without the motivation to bear psychological costs generated by the effort to acquire the knowledge related to 
politics, their understanding of politics is much poorer and their final opinion of politics is often heavily stereotypical. As a consequence, young people can be more susceptible to influence (manipulation) and new, alternative offers do not reach this group.

\section{Conclusion}

The abovementioned obstacles, hindering efficient and valuable two-way communication in relations between political parties and the young people in Poland are showing up in various moments and with varied intensity. These are not evenly distributed over all political parties nor do they apply to the young generation en bloc. There is no doubt however that the distance dividing these two categories is very large and proves dysfunctional from the point of view of the quality of democracy. It is worthwhile to avoid simple and single-factor diagnoses of such a state of affairs. The words of Steven Rosenstone and John Hansen that "citizens participate in elections and government both because they go to politics and because politics comes to them" pointedly summarize the situation (1993, p. 6). The responsibility for the quality of this relation is both on the side of the youth and political elites. The faults however, cannot be evenly distributed. It is the politicians that hold political positions that (1) allow them to and (2) oblige them to promote positive civic behaviour patterns. The obstacles mentioned in this article are a challenge that the politicians ought to notice and accept but also address, since the attitudes of today's youth will shape the "democracy of tomorrow" (Putnam, 1993; Putnam, 2000; Putnam, 1995; Skocpol and Fiorina, 1999; Norris, 2002; Krishna, 2002; Muller and Seligson, 1994). The importance of this issue is emphasised by Joerg Forbrig: "young people also figure prominently in relation to democratic legitimacy. Legitimacy (...) involves (and is mediated by) individual perceptions and beliefs, values and identities, skills and knowledge. These frames of reference, in turn, are the product of political socialization, and childhood, adolescence and early adulthood have long been recognised as the fundamental formative periods, after which any profound changes become much less likely. As a result, future democratic legitimacy is, to some extent, determined by the political socialization young people undergo today" (2005, p. 13-14). The political parties and their leader can therefore play a role of a "helmsman" for the "drifting generation" 12 that with a large baggage of often unrealised resources moves into an unknown and unsure direction towards the future. Importantly, this is not only about their own future but about the future of the entire society or political system.

12 By “drifting generation”, Aldona Guzik, Radosław Marzęcki and Łukasz Stach (2015) mean the young Poles born in the late 1980s and early 1990s. 


\section{Rerefences}

ADNANES, M. (2000): Social Upheavals, Anomie and Coping Bulgarian Youth in the Nineties. In: Mitev, P.-E. (ed.): Balkan Youth and Perception of the Other, Sofia: LIK.

ADSETT, M. (2003): Change in Political Era and Demographic Weight as Explanations of Youth 'Disenfranchisement' in Federal Elections in Canada 1965-2000. „Journal of Youth Studies”, vol. 6, no. 3.

AGH, A. (2001): Globalization and Central East European Contries. In: Markowski, R., Wnuk-Lipiński, E. (eds): Transformative Paths in Central and Eastern Europe, Warszawa: Polska Akademia Nauk.

ANTOSZEWSKI, A. (2000): Społeczeństwo obywatelskie a proces konsolidacji demokracji. In: Czajowski, A., Sobkowiak, L. (eds): Studia z teorii polityki, vol.3, Wrocław: Wydawnictwo Uniwersytetu Wrocławskiego.

ANTOSZEWSKI, A. (2004): Wzorce rywalizacji politycznej we współczesnych demokracjach europejskich, Wrocław: Wydawnictwo Uniwersytetu Wrocławskiego.

BARTMIŃSKI, J. (2010): Język IV RP, czyli o karierze przecieku. Problem wiarygodności dyskursu publicznego. In: Czerwiński, R., Nowak, P., Przybylska, R. (eds): Język IV Rzeczypospolitej, Lublin: Wydawnictwo UMCS.

BLUMENTHAL, S. (1982): The Permanent Campaign, New York: Simon and Schuster.

BROMLEY, C., CURTICE, J. (2002): Where Have All The Voters Gone? In: Park, A., Curtice, J., Thomson, K., Jarvis, L., Bromley, C. (eds): British Social Attitudes. The 19th Report, London: SAGE.

CHARNOCK, E. J. (2005): George W. Bush and the Permanent Campaign Trail. „The Public Purpose”, vol. III.

CZYŻEWSKI, M, KOWALSKI, S., PIOTROWSKI, A. (1997): Rytualny chaos. Studium dyskursu publicznego, Kraków: Aureus.

DERMODY, J., HANMER-LLOYD, S. (2008): 21st Century British Youth: Politically Alienated or an Engaged Critical Citizenry? In: Kane, L.T., Poweller, M.R. (eds): Citizenship in the 21st Century, New York: Nova Science Publishers.

DIJK, T.A. van (1993): Elite Discourse and Racism, Newbury Park: SAGE.

DIJK, T.A. van (2012): The Role of the Press in the Reproduction of Racism. In: Messer, M., Schroeder, R., Wodak, R. (eds): Migrations: Interdisciplinary Perspectives, Wien: Springer. 
EASTON, D. (1965): A Systems Analysis of Political Life, New York: Wiley.

FLASH EUROBAROMETER 202 (Young Europeans), The GALLUP Organisation, Brussels. GESIS Data Archive, Cologne. ZA4542.

FOUCALULT, M. (1975): Discipline and Punish: the Birth of the Prison, New York: Random House.

FOUCALULT, M. (1977): The Political Function of the Intellectual, "Radical Philospohy", no. 17.

FOUCAULT, M. (2005): The Discourse on Language and "Truth and Power". In: Wood, D., Medina, J. (eds): Truth: Engagements Across Philosophical Traditions, Oxford: Blackwell.

FORBRIG, J. (2005): Introduction: Democratic Politics, Legitimacy and Youth Participation. In: Forbrig, J. (ed.): Revisiting Youth Political Participation:

Challenges for Research and Democratic Practice in Europe, Strasbourg: Council of Europe Publishing.

GREEN, J.C., SHEA, D.M. (2007): Throwing a Better Party: Local Political Parties and the Youth Vote. In: Green, J.C., Shea, D.M. (eds): Fountain of Youth: Strategies and Tactics for Mobilizing America's Young Voters, Lanham: Rowman and Littlefield.

GUZIK, A., MARZĘCKI, R., STACH, Ł. (2015): Pokolenie '89. Aksjologia i aktywność młodych Polaków, Kraków: Wydawnictwo Naukowe Uniwersytetu Pedagogicznego w Krakowie.

HAACK, P. (2007): Talking Intervention: Foreign Policy Frames and their Conditional Impact on Individual Attitudes, Saarbrücken: VDM Publishing.

HABERMAS, J. (2012): Elected, but how democratic? „The Economist”, 17.03.2012.

HAYES, A.F., SCHEUFELE, D.A., HUGE, M.E. (2006): Nonparticipation as Self-Censorship: Publicly Observable Political Activity in a Polarized Opinion Climate. „Political Behavior”, vol. 28, no. 3.

HELCO, H. (2000): Campaigning and Governing: A Conspectus, In: Ornstein, N., Mann, T. (eds): The Permanent Campaign and Its Future, Washington: Aei Press.

HJARVARD, S. (2008): The Mediatization of Society. A Theory of the Media as Agents of Social and Cultural Change. „Nordicom Review”, no. 29(2).

HOWE, P. (2006): Political Knowledge and Electoral Participation in the Netherlands: Comparisons with the Canadian Case. „International Political Science Review", vol. 27, no. 2.

INGLEHART, R. (1977): The Silent Revolution: Changing Values and Political Styles among Western Publics, Princeton: Princeton University Press. 
INGLEHART, R. (1999): Postmodernization Erodes Respect for Authority, But Increases Support for Democracy. In: Norris, P. (ed.): Critical Citizens, Global Support for Democratic Governance, Oxford: Oxford University Press.

INGLEHART, R., WELZEL, CH. (2005): Modernization, Cultural Change and Democracy. The Human Development Sequence, New York: Cambridge University Press.

KASPROWICZ, D. (2015), The Radical Right in Poland - from the Mainstream to the Margins. In: Minkenberg, M. (ed.): Transforming the Transformation?: The East European Radical Right in the Political Process, New York: Routledge.

KLESNER, J.L. (2007): Social Capital and Political Participation in Latin America: Evidence from Argentina, Chile, Mexico, and Peru. „Latin American Research Review", vol. 42, no. 2.

KOVACHEVA, S. (2005): Will youth rejuvenate the patterns of political participation? In: Forbrig, J. (ed.): Revisiting Youth Political Participation: Challenges for Research and Democratic Practice in Europe, Strasbourg: Council of Europe Publishing.

KRISHNA, A. (2002): Enhancing Political Participation in Democracies: What is the Role of Social Capital? „Comparative Political Studies”, no. 35.

KRÓL, M. (2012): Europa w obliczu końca, Warszawa: Czerwone i Czarne.

ŁABĘDŹ, K. (2003): Odpowiedzialność polityków za niektóre opinie i przekonania społeczeństwa. „Rocznik Nauk Politycznych”, no. 5.

LINZ, J.J. (1978): Crisis, Breakdown, and Reequilibration: The Breakdown of Democratic Regimes, Baltimore: Johns Hopkins University Press.

LINZ, J.J., STEPAN, A. (1996): Problems of Democratic Transition and Consolidation Southern Europe, South America, and Post-Communist Europe, Baltimore: Johns Hopkins University Press.

LIPSET, S.M. (1960): Political Man: The Social Bases of Politics, Garden City: Doubleday.

LUSKIN, R.C. (1987): Measuring Political Sophistication. „American Journal of Political Science", no. 31.

LUSKIN, R.C. (2003): The Heavenly Public: What Would the Ideal Democratic Citizenry Be Like? In: MacKuen, M., Rabinowitz, G. (eds): Electoral Democracy, Ann Arbor: University of Michigan Press.

MAHIDI, M. (2010): The Young and the Rightless? The Protection of Youth Rights in Europe, Brussels: European Youth Forum.

MARMOLA, M. (2012): Odbiór programów partii politycznych a partycypacja polityczna młodzieży. In: Turska-Kawa, A. (ed.): Polityka w opinii młodych. 
Idee - Instytucje - Obywatele, Katowice: Uniwersytet Śląski, 2012.

MARODY, M. (ed.) (1996): Oswajanie rzeczywistości. Między realnym socjalizmem a realną demokracją, Warszawa: Instytut Studiów Społecznych.

MARZĘCKI, R. (2013a): Styl uprawiania polityki. Kształtowanie i utrwalanie podziałów politycznych we współczesnej Polsce, Kraków: Wydawnictwo Naukowe Uniwersytetu Pedagogicznego w Krakowie.

MARZĘCKI，R. (2013b): Młody obywatel we współczesnej demokracji europejskiej, Warszawa: Elipsa.

MARZĘCKI, R. (2013c): Młodzi obywatele a kryzys przywództwa politycznego w Polsce. „Athenaeum. Polskie Studia Politologiczne”, no. 38.

MARZĘCKI, R. (2013d): Young Poles: Undeveloped Political 'Niche'. „Przegląd Politologiczny”, no. 3.

MARZĘCKI, R. (2015): Depolityzacja jako element stylu życia młodzieży. „Przegląd Politologiczny”, no. 1.

McCOMBS, M. (2004): Setting the Agenda: The Mass Media and Public Opinion, Cambridge: Blackwell.

MILLS, C.Wright (1956): The Power Elite, New York: Oxford University Press. MOUFFE, CH. (2005): On the Political, Abingdon: Routledge.

MULLER, E.N., SELIGSON, M.A. (1994): Civic Culture and Democracy: The Question of Causal Relationships. „American Political Science Review”, no. 88. NORRIS, P. (2002): Democratic Phoenix: Reinventing Political Activism, New York: Cambridge University Press.

OFFE, C. (2004): Capitalism by Democratic. Design? Democratic Theory Facing the Triple Transition in East Central Europe. „Social Research”, vol. 71, no 3.

PALSKA, H. (2009): Dawne i obecne badania nad stylami życia. Analiza dwu przypadków. In: Gliński, P., Kościański, A. (eds): Socjologia i Siciński. Style życia - Społeczeństwo obywatelskie - Studia nad przyszłością, Warszawa: Wydawnictwo IFiS PAN.

PARK, A. (1999): Young People and Political Apathy. In: Jowell, R., Curtice, J., Park, A., Thomson, K., Jarvis, L., Bromley, C., Stratford, N. (eds): British Social Attitudes. The 16th Report. Who Shares New Labour Values?, Aldershot: Ashgate.

PRIDHAM, G. (1995): The International Context of Democratic Consolidation: Southern Europe in Comparative Perspective. In: Gunter, R., Diamandouros, P.N. (eds): The Politics of Democratic Consolidation, Baltimore: Johns Hopkins University Press.

PUTNAM, R. D. (1995): Tuning In, Tuning Out: The Strange Disappearance of Social Capital in America. „PS: Political Science and Politics”, no. 28(4). 
PUTNAM., R. D. (1993): Making Democracy Work, Princeton: Princeton Universitiy Press.

PUTNAM., R. D. (2000): Bowling Alone: The Collapse and Revival of American Community, New York: Simon and Schuster.

ROSENSTONE, S.J., HANSEN, J.M. (1993): Mobilization, Participation, and Democracy in America, New York: Macmillan Publishing Company.

RUSSELL, A., FIELDHOUSE, E., PURDAM, K., KALRA, V. (eds) (2002):

Voter Engagement and Young People, London: The Electoral Commission, http://www.electoralcommission.org.uk (5.05.2015).

SCHMITTER, P H. (1994): Dangers and Dilemmas of Democracy. "Journal of Democracy", vol. 5 , no. 2.

SCHUMPETER, J. A. (1976): Capitalism, Socialism, and Democracy, London: Allen and Unwin.

SIMLAT, M. (2008): Niektórzy obywatele nie są Obywatelami. In: Łabędź, K. (ed.): Bariery aktywności publicznej, Toruń: Wydawnictwo Adam Marszałek. SKOCPOL, T., FIORINA, M. P. (eds) (1999): Civic Engagement in American Democracy, Washington: Brookings Institution Press.

STRÖMBÄCK, J. (2008): Four Phases of Mediatization: An Analysis of the Mediatization of Politics. ,The International Journal of Press/Politics”, no. 13(3). STRÖMBÄCK, J., DIMITROVA, D. V. (2006): Political and Media Systems Matter: A Comparison of Election News Coverage in Sweden and the United States. „The International Journal of Press/Politics”, no. 11/4.

STRÖMBÄCK, J., LUENGO, O. G. (2008): Polarized Pluralist and Democratic Corporatist Models: A Comparison of Election News Coverage in Spain and Sweden. „International Communication Gazette”, no. 70/6.

SVYNARENKO, A. (2001): National, Political and Cultural Identities of Youth:

Tendencies in Post-Soviet Ukraine. In: Helve, H., Wallace, C. (eds): Youth,

Citizenship and Empowerment, Aldershot: Ashgate.

SZTOMPKA, P. (1991): Society in Action. The Theory of Social Becoming, Chicago: The University of Chicago Press.

SZTOMPKA, P. (1993): The Sociology of Social Change, Oxford: Blackwell. SZTOMPKA, P. (2007): Zaufanie. Fundament społeczeństwa, Kraków: Znak.

TERRÉN, E. (2002): Post-modern Attitudes: A Challenge to Democratic Education. „European Journal of Education”, vol. 37, no. 2.

TIVADAR, B., POLONA, M. (eds) (2002) : Flying Over or Falling Through the Cracks? Young People in the Risk Society, Ljubljana: Ministry of Education, Science and Sport of the Republic of Slovenia, Office of the Republic of Slovenia for Youth.

TYYSKÄ, V. (2009): Youth and Society: The Long and Winding Road, Toronto: 
Canadian Scholars' Press.

VRCAN, S. (2002): Youth: Politics, Sub-Politics and Anti-Politics. The Case of Croatia Since the Mid-eighties. In: Tivadar, B., Polona, M. (eds): Flying Over or Falling Through the Cracks? Young People in the Risk Society, Ljubljana: Ministry of Education, Science and Sport of the Republic of Slovenia, Office of the Republic of Slovenia for Youth.

VREESE, C.H. de, BOOMGAARDEN, H. G. (2006): Media Message Flows and Interpersonal Communication The Conditional Nature of Effects on Public Opinion. „Communication Research”, vol. 33, no. 1.

WAYNE, B. , MACKENZIE, C., COLE, R. (2006): Conflict and Consensus in American Politics, Belmont: Cengage Learning,.

WNUK-LIPIŃSKI, E. (2005): Socjologia życia publicznego, Warszawa: Wydawnictwo Naukowe SCHOLAR.

ZALLER, J. (1992): The Nature and Origins of Mass Opinion, Cambridge: Cambridge University Press. 